\title{
Freire, Fermento Entre os Oprimidos: Continua Sendo?
}

\author{
Freire: Can He Still be Considered a Yeast Among the Oppressed?
}

Décio Auler

Palavras-chave Resumo Freire busca colocar os oprimidos no palco da história.

Paulo Freire; PLACTS;

Diálogo de saberes;

Agenda do

oprimido;

Pedagogia do

oprimido;

Educação do campo.
Contudo, uma efetiva emersão, enquanto sujeitos históricos, fica fragilizada considerando que há uma incompletude: suas demandas continuam sendo, majoritariamente, trabalhadas pelos conhecimentos e práticas demandadas pelos opressores. Está frágil, em Freire, a compreensão de que conhecimentos e práticas hospedam valores. Teorização resultante de aproximação entre Freire e o Pensamento Latino-americano em Ciência-Tecnologia-Sociedade (PLACTS) busca trabalhar essa incompletude. Assim, quais desafios e possibilidades, relacionadas a essa dinâmica teórico-metodológica, colocam-se quando dialogam processos produtivos e educativos? Exemplar de uma práxis, implementada no contexto da produção de alimentos segundo princípios da agroecologia, é analisada. Dessa reflexão conclui-se pela necessidade de, para superar incompletude apontada, ampliar a categoria diálogo, de Freire, para diálogo de saberes no qual dialogam três campos: os denominados conhecimentos produzidos historicamente, os conhecimentos inéditos (resultantes do enfrentamento de demandas situadas entre os oprimidos, ignoradas historicamente) e a memória biocultural. Desse processo, surgem duas novas categorias ainda incipientes: coprodução e coaprendizagem, as quais, sinalizando novos horizontes para processos produtivos e educativos, nutrem-se do diálogo entre ambos. Diálogo entre agenda de pesquisa do oprimido e pedagogia do oprimido. 
Keywords Abstract Freire intends to bring the oppressed onto the stage of Paulo Freire; history. However, their emergence as historical subjects is weakened PLACTS; as long as there is an incompleteness: their demands continue to be Knowledge worked out by knowledge and practices demanded by the oppressors. dialogue; In Freire's work, it is quite unclear if knowledge and practices are

Agenda of the oppressed; Pedagogy of the oppressed; Rural education. considered to host values. The theorization that emerges from the approximation between Freire and the Latin American Thought in Science, Technology and Society (PLACTS) seeks to work on this incompleteness. So, which challenges and possibilities related to this theoretical-methodological framework arise when productive and educational processes dialogue? We analyzed an example of praxis implemented in the context of food production according to the principles of agroecology. From the reflection on this praxis, we concluded that, in order to overcome said incompleteness, Freire's conception of dialogue should be expanded to encompass a dialogue of knowledge between three fields: the so-called historically produced knowledge, the unpublished knowledge (resulting upon conflict confrontation over ignored demands among the oppressed) and biocultural memory. From this process, two new categories arise, which are still incipient: co-production and co-learning, which, signaling new horizons for productive and educational processes, are nourished by the dialogue between both. This is a dialogue between the agenda of the oppressed and the pedagogy of the oppressed.

\section{Introdução}

A pertinência de encaminhamento teórico-metodológico, resultante da aproximação entre Freire e o Pensamento Latino-americano em Ciência-TecnologiaSociedade (PLACTS), tem sido analisada em alguns trabalhos, a exemplo de Delizoicov e Auler (2011), Auler e Delizoicov (2015) e Santos e Auler (2019). Nesses, argumentase sobre a necessidade da identificação de demandas historicamente negligenciadas, negligenciadas porque situadas entre os excluídos. Demandas geradoras de currículos, geradoras de agendas de pesquisa. No presente artigo, focaliza-se a pesquisa não dissociada do ensino e da extensão, em contextos de interfaces entre educação do campo e educação em ciências. Também, altera-se a tradicional apresentação do tripé, que dinamiza o funcionamento da universidade, "ensino-pesquisa-extensão" para "extensão-ensinopesquisa”.

Pelo cenário tendencial atual (mudanças climáticas, degradação socioambiental, progressiva escassez de combustíveis fósseis), o fazer pesquisa poderá ocorrer num mundo social e natural bastante distinto daquele que, até hoje, tem sido foco das mesmas. Talvez com uma profunda intensificação das mazelas sociais problematizadas e foco 
do fazer educação de Freire. Degradação do mundo social e natural cada vez menos separáveis. Mundo natural não constituindo foco das teorizações de Freire. Cada vez mais, surgem indicativos da necessidade e da viabilidade de intensificar o diálogo entre esses dois âmbitos, o que remete também a, em processos de extensão-ensino-pesquisa, intensificar o diálogo entre processos produtivos e educativos.

Em práxis em curso ${ }^{1}$, emergem indicativos da pertinência do referencial freireano para o cenário brevemente caracterizado. Contudo, havendo a necessidade de trabalhar incompletudes do mesmo, as quais são inerentes a processos históricos. Incompletudes, hoje, mais evidentes considerando a densificação de elementos empíricos e teóricos ainda frágeis nos espaços-tempos em que atuou. Fragilidade trabalhada, hoje, com a recorrência a um novo referencial: o PLACTS e sua atualização e aprofundamento realizado, dentre outros, pelo professor da Unicamp Renato Dagnino (Dagnino, 2008, 2010a, 2010b e 2019). Incompletude, em Freire, relacionada ao fato de não fazer parte do seu escopo de trabalho o mundo natural e a problematização do conteúdo dos processos produtivos.

Em determinados contextos, há uma afirmação que é recorrente: "Freire já era". Não, Freire continua sendo. Sua obra representa um referencial não aprisionável, não sufocável. Depois que se disseminou, discursos desqualificadores não conseguem mais apagá-lo. Onde houver oprimidos, por mais que tentem sufocá-lo e silenciá-lo, rebrota, renasce em diferentes espaços-tempo, amplificando as vozes dos condenados da terra. Enquanto houver oprimidos, esse referencial continua atual e necessário. Fermento que faz crescer.

Freire não foi um milagreiro que, em curtos espaços de tempo, obtinha resultados promissores no processo de alfabetização de adultos, acompanhados de um processo de conscientização que os fazia perguntar por quê??, contribuindo para sua emersão da cultura do silêncio, passando a lutar pela condição de sujeitos históricos e não meros objetos dos interesses de outros. O fundamento desses êxitos está relacionado a sua opção em respeitar, em considerar, como ponto de partida, em processos educativos, os problemas, a vida vivida pelas comunidades, dimensão associada ao que denomina de curiosidade epistemológica. Sua infância, suas raízes sustentam e inspiram essa opção: "Minha alfabetização não me foi nada enfadonha, porque partiu de palavras e frases ligadas à minha experiência, escritas com gravetos no chão de terra do quintal" (Freire, 1995, p. 31).

Se outros já haviam intuído a pertinência desse caminho, o inédito em sua caminhada está na constituição de categorias que fundamentam e instrumentalizam o processo. Categorias como tema gerador; investigação temática; curiosidade epistemológica; educação dialógica e problematizadora (libertadora) em contraposição à educação bancária; diálogo e problematização; situação-limite e inédito-viável; consciência ingênua e consciência máxima possível.

1 http://w3.ufsm.br/pre/images/pdfs/RegimentoIncubadora.PDF. 
"Me reinventem", desafio constantemente lançado por ele. Nesse sentido, temse, no campo da educação em ciências, caminhada relevante. Freire inicia suas práxis, predominantemente, no espaço da alfabetização de adultos, na denominada educação não formal. Um dos focos esteve constituído dos oprimidos do campo. Por exemplo, no Nordeste brasileiro, com a experiência de Angicos. No Chile, num processo que conjugava alfabetização, reforma agrária e a denominada modernização do campo. Assim como em Guiné Bissau no continente africano. A caminhada, na educação em ciências, inicia na transposição dessa concepção educacional para o espaço da educação formal. $\mathrm{O}$ começo pode ser situado nos anos 80 quando um grupo de Físicos da USP, coordenado por Luiz Carlos de Menezes, pergunta: o que Freire tem a dizer para o ensino de física? Assim nasce o Grupo de Reelaboração para o Ensino de Física, mais conhecido como GREF. Integrantes desse grupo, José André Peres Angotti (1982) e Demétrio Delizoicov (1980 e 1982) passam a trabalhar conjuntamente com Paulo Freire na Guiné Bissau.

Os, hoje, conhecidos e difundidos três momentos pedagógicos (Delizoicov, 1991) e (Angotti \& Delizoicov, 1990) trabalhados principalmente por Delizoicov, têm sua gênese nesse espaço-tempo. Constitui dinâmica de trabalho, inspirada no referencial freireano, para o espaço da educação formal. Posteriormente, no Brasil, teorizações resultantes dessas caminhadas constituem referência para políticas públicas, para trabalhos realizados em universidades com comunidades, para múltiplas pesquisas, muitas dessas resultando em dissertações e teses. (Delizoicov et al., 2013; Pernambuco et al., 1988; Silva, 2004; Pontuschka, 1993; Muenchen, 2010). Também Brick et al. (2014) em projeto sobre educação do campo alicerçado em Freire.

Em Auler (2002) inicia-se aproximação crítica entre o referencial freireano e o denominado movimento Ciência-Tecnologia-Sociedade (CTS). Os resultados dessa caminhada encontram-se em Auler e Delizoicov (2006). Para Freire (1987), educação relaciona-se com conhecimento crítico da realidade, com uma leitura crítica do mundo. Esse se constitui no ponto central dessa aproximação. Para uma leitura crítica do mundo contemporâneo, cuja dinâmica está crescentemente relacionada ao desenvolvimento científico-tecnológico, considera-se fundamental uma compreensão crítica das interações entre Ciência-Tecnologia-Sociedade (CTS).

Passa-se a compreender melhor que uma postura fatalista, uma percepção ingênua da realidade pode estar sendo realimentada por construções históricas (suposta superioridade do modelo de decisões tecnocráticas, o salvacionismo atribuído à CiênciaTecnologia (CT) e o determinismo científico-tecnológico), considerando que, dentre outras características, podem exercer efeito paralisante. Ainda, em Auler e Delizoicov (2006), entende-se que os fatalismos, aos quais Freire constantemente faz referência, manifestavam-se, no campo científico-tecnológico, por exemplo, sob a forma de determinismos tecnológicos (caminho único), em manifestações do tipo "não podemos deter o avanço tecnológico", "o desemprego no mundo é uma fatalidade do fim do século". Uma síntese dessa aproximação encontra-se em Auler (2007), na qual destacamse três eixos: currículos temáticos, abordagens interdisciplinares e democratização de processos decisórios. 
Nesse ponto da caminhada, referente a aproximação Freire-CTS, inquietações e dúvidas passaram a não mais ser negligenciáveis. Com a polissemia presente, no campo CTS, muitos de seus encaminhamentos foram abandonados, considerando constituírem ratificações do status quo. Se a preocupação com a ausência, em Freire, do denominado "mundo natural", estava sendo parcialmente contemplada com as preocupações ambientais presentes em encaminhamentos CTS/CTSA, havia questões de fundo que incomodavam. Qual o alcance da postulada cultura de participação? Em linhas gerais, a submissão ao colonialismo persistia. $\mathrm{O}$ conceito de participação era importado. Participação, na maioria dos trabalhos do campo CTS, significando participar da avaliação dos impactos da Ciência-Tecnologia (CT) na sociedade (S). Praticamente ausentes discussões sobre impactos da Sociedade (S), ou melhor, das elites de cada período histórico, sobre o direcionamento dado ao desenvolvimento científicotecnológico (CT). De outra forma, uma participação no "pós". Participação após a definição da agenda de pesquisa, após a definição da Política Científico-Tecnológica, após a produção. $\mathrm{O}$ conteúdo dos processos produtivos está fora do alcance, em termos de problematização, de participação, para o conjunto da sociedade. O mesmo ocorrendo em práxis freireanas.

Reflexões associadas a práticas efetivadas (Delizoicov \& Auler, 2011), (Auler \& Delizoicov, 2015) e (Santos \& Auler, 2019) revelaram a pertinência do referencial latinoamericano PLACTS na ampliação do conceito de participação ${ }^{2}$. Essa compreensão colocou novos desafios para a extensão, o ensino e a pesquisa, assumidos em projeto desenvolvido em Universidade Federal. Dessa caminhada amadurece a pergunta que guia as reflexões do presente artigo: Quais desafios e possibilidades, relacionadas à dinâmica teórico-metodológica resultante da aproximação Freire-PLACTS, colocam-se em práxis na qual dialogam processos produtivos e educativos no contexto da produção de alimentos segundo princípios da agroecologia?

\section{Incompletude no referencial freireano}

Sistematicamente, Freire desafiava: "Me reinventem". Este artigo quer somarse ao conjunto de iniciativas que buscam aceitar o desafio lançado. Reinvenção que, preservando a essência da obra do autor, está alicerçada em elementos não presentes naquele tempo histórico. $\mathrm{O}$ eixo da presente argumentação, buscando avanços, está em problematizar, em avançar para além do olhar excessivamente generoso de Freire em relação às forças produtivas capitalistas, em relação à Ciência-Tecnologia capitalista, ou com terminologia mais contemporânea, a tecnociência ${ }^{3}$ capitalista. Naquele tempo,

2 A aproximação Freire-PLACTS, com a ampliação do conceito de participação, sinalizou desafios para novas pesquisas. Por exemplo, Rosa (2019), Strieder (2012), Archanjo e Gehlen (2020) e Roso (2017).

3 Dagnino (2019) fundamenta e trabalha o conceito de tecnociência solidária, contrapondo-o ao de tecnociência capitalista. 
o poder destrutivo das forças produtivas capitalistas, particularmente no campo da agricultura, ainda não havia manifestado ${ }^{4}$, como hoje, seu poder degradante.

Foi, principalmente, no contexto da reforma agrária chilena, de práxis ali efetivadas, que Freire legou-nos obras como Extensão ou Comunicação? (2002) e Pedagogia do Oprimido (1987). Com centralidade em ambos, a categoria diálogo constitui eixo que fundamenta a escrita deste artigo. Não propriamente uma reinvenção, mas um agregar de dimensões não presentes ou incipientes no espaço-tempo chileno. Hoje, temos elementos para trabalhar essa incompletude em sua obra. Elementos que, amplificando e potencializando a categoria diálogo, resultam no diálogo de saberes, o qual passou a ter centralidade no campo da agroecologia. Em práxis em curso, já referida, dinamizada na interação entre extensão, ensino e pesquisa, esse diálogo de saberes tem sinalizado e ajudado a fundamentar duas categorias, em constituição, mediante as quais busca-se fundamentar o diálogo entre processos produtivos e educativos: coprodução ${ }^{5}$ (CP) e coaprendizagem (CA).

Extensão ou Comunicação?, obra publicada por Paulo Freire em 1969, constitui, se não a principal, uma das principais referências, não somente na América Latina, que ilumina caminhos que buscam superar modelos tecnocráticos no âmbito da extensão universitária e, mais recentemente, em cursos de educação do campo. Hoje, após 50 anos, tem-se elementos não presentes ou não identificados/problematizados naquele espaço-tempo. Elementos que podem contribuir para complementar, para aprofundar o potencial crítico e, principalmente, transformador dessa práxis. Ao longo do presente texto, argumenta-se que o potencial transformador pode ter ficado fragilizado, considerando que as forças produtivas capitalistas, a CT capitalistas não foram consideradas espaços, conteúdos de problematização. $\mathrm{O}$ sistema produtivo foi concebido como "um dado", sem a necessidade de sua problematização. Algo como, hoje, não problematizar a biotecnologia do agronegócio com seu exemplar significativo: os transgênicos.

A associação entre reforma agrária e modernização da agricultura, desde sua origem, estava significando a progressiva implementação da denominada revolução verde. Inicialmente, quando Freire começa a trabalhar, no Chile, possivelmente modernização técnica ainda não estivesse significando os pacotes da revolução verde. Contudo, inquieta-me o fato de não ter problematizado essa modernização vinda do capital. Era considerada neutra? A única possível? Também, ele chega, em 1964, como exilado. Não seria razoável imiscuir-se na política interna do país, em acordos assinados anteriormente (Aliança para o Progresso). Engaja-se num coletivo que, aproveitando

4 Em 2013, em Recife, no Congresso Nacional sobre Educação em Agroecologia, a conferência de abertura foi ministrada por Carlos Rodrigues Brandão. Remanescente de um coletivo de educadores, companheiros de jornada de Freire, Brandão, agora engajado nos princípios da agroecologia, relembrou de falas com Freire quando ambos se perguntavam, na década de 60, do século passado, sobre o que e quem estaria por trás dos movimentos ambientais. Seria para frear/impedir o desenvolvimento do Hemisfério Sul? Cabe destacar que, naquele espaçotempo, problemas associados à degradação socioambiental estavam apenas latentes, não havendo a percepção de sua profundidade.

5 A categoria coprodução foi inspirada em trabalho relatado por Samagaia (2016). 
brechas (a reforma agrária e a modernização da agricultura como um processo participativo), busca, num campo até então dominado pela racionalidade tecnocrática, trabalhar uma nova concepção de extensão alicerçada, dentre outras, nas categorias diálogo e problematização.

Nesse espaço-tempo chileno, se havia dissensos sobre o modelo de reforma agrária, não foram identificados em relação à modernização da agricultura. Salvo fontes inacessíveis, havia um amplo consenso (incluindo o campo da esquerda) de que, para aumentar a eficiência e a produtividade, as técnicas mais modernas eram imprescindíveis, traduzidas, no processo, nos pacotes da revolução verde. Ou seja, num cenário de carência alimentar, com a promessa de que a tecnologia de ponta, já disponível, associada à reforma agrária, enfrentaria esse flagelo, configurou-se um contexto favorável e refratário a qualquer problematização da progressiva implementação da revolução verde.

O processo histórico revelou que, efetivamente, não se tratava de técnicas neutras, mas portadora de valores, de características, de interesses do capital. Com os elementos, hoje presentes, fica, cada vez mais, difícil um olhar tão generoso sobre essa modernização técnica que culminou na revolução verde. Essa modernização da agricultura, passando pela revolução verde, assumiu centralidade a ponto de, atualmente, mediante um processo de artificialização, essa agricultura industrial passou a ser denominada de convencional. Como resultado, referindo-se à agricultura do Chile contemporâneo, o agrônomo Mundaca expressa,

A agricultura praticada no Chile implica na simplificação da biodiversidade e atinge uma forma extrema nas monoculturas. O resultado final é uma produção artificial que requer constante intervenção humana. Na maioria dos casos, essa intervenção ocorre na forma de insumos: pesticidas e fertilizantes químicos que, apesar de aumentarem a produtividade no curto prazo, resultam em custos ambientais e sociais de magnitudes impossíveis de quantificar. (Mundaca, 2015, p. 2)

Essa caracterização não é exclusiva do Chile. A denominada agricultura convencional literalmente tomou conta. A revolução verde consistiu num processo planetário. Hoje, segundo Mundaca (2015), produzimos mais alimentos, mais pessoas estão passando fome e estamos mais envenenados.

Naquele contexto chileno, não estava suficientemente compreendido no que implica a apropriação das forças produtivas ${ }^{6}$ capitalistas em termos de reprodução das relações sociais de produção ${ }^{7}$. Acreditou-se que as técnicas capitalistas (técnicas mais modernas) pudessem ter uso distinto daquele definido pelos interesses do capital. Varsavsky (1976), falando em termos gerais, sem se referir especificamente à agricultura, foi pioneiro na problematização dessa compreensão: "Nem todo estilo ${ }^{8}$ científico será compatível com determinado estilo de sociedade" (p. 14). Extrapolando o conceito de

6 Conceito de origem marxista, as forças produtivas são constituídas pelos meios de produção - capitais, terras, matérias-primas, ferramentas e equipamentos -, pelos métodos e técnicas de utilização e pelos trabalhadores.

7 Resumidamente, as relações de produção são as formas como os seres humanos desenvolvem suas relações de trabalho e distribuição no processo de produção e reprodução da vida material.

8 Varsavsky destaca que o termo "estilo" tem alguma semelhança com o conceito de paradigma de Kuhn (1998). 
paradigma para âmbito não autorizado por Kuhn (1998), hoje, tem-se a compreensão de que há uma correspondência, uma relação de mútuo reforço e de dependência entre paradigmas produtivos e paradigmas científicos.

Assim, “...em geral, cada tipo de sociedade exige um estilo de ciência próprio, diferente pelo seu conteúdo, seus problemas prioritários, seus métodos de pesquisa e seus critérios práticos de verdade, assim como pelas características sociológicas do grupo de pesquisadores". (Varsavsky, 1976, p. 7)

A modernização ocorrida no Chile, estando vinculada a um processo de reforma agrária, permitiu uma práxis que atingiu determinados níveis de conscientização. Atingiu-se níveis que permitiram uma compreensão crítica das relações sociais de produção. Mas práxis insuficientes para uma efetiva transformação das forças produtivas. Constituíram práxis em que Freire fundamenta a categoria inédito-viável. Contudo, ele próprio não conseguiu avançar na compreensão de que o inédito-viável, uma sociedade menos feia, não é alcançável, apenas, com a apropriação, com o uso das forças produtivas capitalistas. Ou seja, nesse caso, com as denominadas técnicas modernas. Freire não conseguiu captar, apesar de ajudar a fundamentar, o novo inédito-viável que estava no horizonte: uma agricultura pautada nos princípios da agroecologia.

\section{Por que extensão-ensino-pesquisa?}

Anteriormente, destacou-se que, na caminhada, houve a constatação da necessidade de alargar o conceito de participação em processos decisórios envolvendo o campo científico-tecnológico. Constatação aguçada por uma compreensão ampliada sobre a não neutralidade da CT (Delizoicov \& Auler, 2011). Nessa, passamos a entender que a gênese da mesma situa-se no âmbito da seleção dos problemas que são investigados. Em outros termos, na definição da agenda de pesquisa, na formulação da Política Científico-Tecnológica. Seleção, definição e formulação condicionadas pelo campo dos valores.

O PLACTS/Dagnino constitui referencial fundamental para esse alargamento do conceito de participação. Alargamento ausente tanto no referencial freirenao quanto no do campo CTS. Ações de extensão, ensino e pesquisa passaram a ser fundamentadas por teorização resultante de aproximação crítica entre Freire e o PLACTS/Dagnino. Duas práxis genuínas, do contexto latino-americano, que surgiram a partir dos anos 1960. Práxis originais, enraizadas em elementos locais, compartilhando convicções muito próximas. Assentadas em pressupostos comuns e complementares. Complementares porque se, de um lado, Freire trabalha dimensões bastante inéditas, no campo educacional, não se dedica a aprofundar o campo da Ciência-Tecnologia, o qual constitui o foco do PLACTS que, por outro lado, está um tanto afastado do educacional.

Sustentadas em pressupostos comuns, considerando que, em ambas, postula-se a superação da separação entre concepção e execução. Na concepção educacional bancária, foco principal da crítica de Freire, alguns concebem o currículo, outros o executam. No campo da Ciência-Tecnologia (CT), executa-se, no contexto latino-americano, segundo 
os representantes do PLACTS, uma agenda de pesquisa concebida no Hemisfério Norte. Em ambos os referenciais, o ponto de partida, sinalizando novos horizontes, está em romper com essa separação entre conceber e executar, subvertendo a essência da lógica capitalista, conforme caracterizada, dentre outros, por Braverman (1987).

Outro trabalho (Auler \& Delizoicov, 2015), o qual buscou aprofundar a compreensão sobre complementaridades entre essas duas práxis, foi guiado pela pergunta: como inserir demandas sociais, historicamente ignoradas, na produção do conhecimento científico-tecnológico? A busca por respostas passou pela compreensão de que a gênese da não neutralidade da CT está na seleção de demandas. Seleção fortemente influenciada por valores. Como conclusão destaca que, com o processo de investigação temática freireana, mediante a inserção de novos atores sociais - inclusive pesquisadores em CT formados contra-hegemonicamente numa perspectiva que tem sintonia com o PLACTS -, novas demandas são colocadas em pauta e novos/outros valores emergem.

A teorização resultante do encontro desses dois referenciais sinaliza para uma complementaridade que articula um fazer educativo (Freire) e um fazer pesquisa (PLACTS), em que currículos e agendas de pesquisa são geradas num processo coletivo de aprendizagem. O horizonte vislumbrado está em conceber currículos, conceber agendas de pesquisa originadas de demandas de segmentos sociais historicamente negligenciados. $\mathrm{Na}$ identificação das mesmas, a investigação temática freireana tem centralidade.

Com essa teorização houve avanços na compreensão sobre o papel dos valores no processo científico-tecnológico. Freire aborda-os intensamente em suas práxis. Seu papel no processo de humanização. Contudo, a limitação está em silenciar sobre o papel dos valores no direcionamento dado ao desenvolvimento científico-tecnológico. Também ausente, assim, a compreensão de que o produto científico-tecnológico assume características associadas aos valores demandantes. Nesse sentido, um bom exemplo contemporâneo consiste na tecnologia terminator ${ }^{9}$. Possíveis problemas relacionados ao uso desses produtos não decorrem apenas do mau uso dos mesmos, conforme o senso comum entende. Tais problemas estão latentes. Sua ocorrência decorre da materialização de interesses, associados a determinados valores, que foram projetados nos produtos. Em outros termos, o produto incorpora, assume configurações, materializa características associadas aos valores presentes em sua gênese.

Varsavsky (1976), físico-matemático, pesquisador argentino, integrante e pioneiro do PLACTS, havia compreendido que valores, presentes no espaço social mais amplo, eram definidores de problemas a serem investigados,

9 Por exemplo, sementes nas quais foi introduzido o gene terminator não nascem porque foram plantadas de forma incorreta, porque tiveram um mau uso. O não nascimento estava projetado, programado. As sementes híbridas, introduzidas na revolução verde, somente tornam-se produtivas quando alimentadas pelo conteúdo dos pacotes da mesma. Isso não significa concluir que todos os avanços, no campo científico-tecnológico, estiveram destituídos de altruísmo. Mas que seus produtos carregam marcas, características dos espaços-tempo em que foram concebidos. A tecnologia terminator está aguardando aprovação, para sua implementação, no Congresso Nacional. 
Em resumo, o que se investiga numa sociedade é o que essa sociedade considera suficientemente importante. A importância de um problema nada tem a ver com a verdade de suas possíveis respostas; depende dos valores (grifo do autor) predominantes sendo, portanto, uma característica ideológica. Diferentes estilos sociais fixarão diferentes prioridades - isto é, recursos - e farão a ciência progredir em direções diferentes. (Varsavsky, 1976, p. 44)

O PLACTS surge num momento histórico em que está em pauta a denominada transferência tecnológica. Esse pensamento empreende uma práxis que questiona esse modelo de industrialização. Seus representantes, Varsavsky $(1969,1976)$, Herrera (1971, 1973) e Sábato (1982), dentre outros, na sua maioria eram pesquisadores no campo das chamadas ciências naturais, vinculados a universidades argentinas. Já, nas décadas de 60 e 70, do século passado, destacavam que, no processo de transferência tecnológica, não estavam sendo transferidas ferramentas neutras, mas modelos de sociedade. Propuseram a concepção de uma política científico-tecnológica (PCT), de agendas de pesquisa a partir de demandas da maioria da sociedade, historicamente relegadas.

Como síntese da referida aproximação Freire-PLACTS, concluiu-se que:

Defendemos uma complementaridade que articula um fazer educativo (Freire) e um fazer pesquisa (PLACTS), em que currículos e agenda de pesquisa são gerados num processo coletivo de aprendizagem. Como encaminhamento propomos que temas, que passamos a denominar temas CTS, os quais têm como característica constituírem demandas historicamente relegadas, assumam o papel de temas geradores, gerando currículos, nos vários níveis de ensino, e agendas de pesquisa. (Auler \& Delizoicov, 2015, p. 293)

O campo político engajado na construção de sociedades distintas do capitalismo, perdeu muito tempo, ou melhor, necessitou de um longo tempo para amadurecer a compreensão sobre o papel dos valores materializados, dos interesses e características internalizadas, enquanto correia transmissora da lógica do capital. Constitui semente da qual constantemente brotam reafirmações do status quo a ideia de que a cultura elaborada, as forças produtivas, os meios de produção estão aí, sob o poder de poucos, sendo necessária a luta de classes para socializá-los. A coisa é bem mais complexa. Essa coisa, seu processo de produção e circulação é pautado pelo valor troca para a geração de lucro privado, não pelo valor de uso (efetiva necessidade social). Há todo um conjunto de valores, de hábitos, de interesses materializados nessa lógica que precisam ser problematizados e reelaborados, presentes na cultura elaborada, nas forças produtivas.

Santos e Auler (2019) sinalizam a necessidade de inserir um novo objetivo na educação, particularmente na educação em ciências: a busca de uma participação social na definição de agendas de pesquisa, de PCT marcadas por demandas de segmentos sociais até então excluídos. Objetivo em processo de materialização em contextos da educação não formal, como nas caminhadas sobre agroecologia, nas incubadoras sociais. Destaca-se que não é construtivo, numa perspectiva educacional crítica e 
transformadora, continuar silenciando, sem sinalizar novos horizontes, sobre valores assimilados e omitidos no processo científico-tecnológico atual. Também compreendeuse melhor que, demandas não situadas no contexto das elites dominantes de distintos momentos históricos, ou demandas não funcionais à perpetuação do capital, têm sido negligenciadas. Por exemplo: aproveitamento da energia solar, agroecologia, medicina social/preventiva, plantas medicinais, soberania alimentar, influência da lua nas plantações, eficiência energética e sustentabilidade da agroecologia e do agronegócio.

Como título desta seção comparece: Por que extensão-ensino-pesquisa quando, sem exceções, utiliza-se a nomenclatura ensino-pesquisa-extensão. Não se trata de mero jogo de palavras. A dinâmica hegemônica no funcionamento da universidade coloca a pesquisa como propulsora. Conhecimentos e práticas, resultantes da mesma, alimentam currículos (ensino), são estendidos para a comunidade (extensão). Nessa dinâmica, silencia-se, omite-se algo central: quem e com que valores e interesses definiu o que seria pesquisado? Uma das consequências dessa dinâmica pode ser analisada na concepção hegemônica de extensão: estende-se, para a comunidade, um conhecimento, práticas não demandadas pela mesma. Não foram seus problemas que demandaram as pesquisas e os conhecimentos resultantes. Por exemplo, a tecnologia terminator não foi demandada pelos agricultores(as). Foi criada para torná-los reféns de algumas poucas transnacionais vendedoras de sementes. Perdendo o controle, a autonomia sobre o processo produtivo. Gerando dependência.

Resumidamente, inverte-se a ordem do tripé para ser coerente com Freire. Também com teorização de Dagnino (2010a) quando esse defende o "Começar pela Extensão". No início do artigo, quando foi destacado que os resultados alcançados por Freire não eram decorrência da ação de um milagreiro, mas que, via investigação temática, estava propondo algo bastante inédito: estruturar o currículo em torno de eixos: os temas geradores. Temas que carregam para o currículo a vida das pessoas da comunidade. Se foi alargada a abrangência da investigação temática no sentido de, além de constituir estruturante de currículos, também estruturar agendas de pesquisa, é consistente e necessário que essas agendas tenham como ponto de partida os problemas vividos pela comunidade.

Sem partir de premissas freireanas, Dagnino (2010a) propõe encaminhamento teórico-metodológico muito próximo. Encaminhamento que denomina de "Começando pela extensão". A extensão deixa de ser o ponto de chegada, no qual desaguam conhecimentos e práticas não demandadas por problemas das comunidades onde são estendidas. Propõe substituir extensão por intenção no sentido de internalizar, de trazer para o âmbito acadêmico problemas vivenciados pela comunidade. Problemas sociais são transformados em problemas de conhecimento.

Começando pela extensão, na caminhada que analiso, ainda que de forma pontual, implicou em profundo redimensionamento do tradicional tripé ensinopesquisa-extensão que organiza a dinâmica de funcionamento da universidade. Também a dinâmica de ensino e pesquisa foi afetada. Por que o ensino antes da 
pesquisa? Resumidamente, por ensino, nessa nova dinâmica, entende-se conhecer o que a humanidade já conhece sobre o problema demandado pela comunidade, identificado na extensão. Muitas vezes, como aconteceu em alguns dos projetos da Incubadora Social, não há a necessidade de pesquisas novas, inéditas. Os conhecimentos disponíveis são suficientes e relevantes para o enfrentamento do problema. Numa concepção não bancária de ensino, o desafio, a demanda gerada faz com que o coletivo se envolva em conhecer mais sobre o problema. Vai em busca. Algo parecido com a revisão bibliográfica que fazemos numa pesquisa convencional. O coletivo busca saber o que já se sabe, o que inclui o diálogo com a memória biocultural no caso da agroecologia. Supera-se, assim, a concepção propedêutica no ensino. $\mathrm{O}$ currículo passa a ser gerado, demandado pelo tema, pelo problema investigado.

Conhecido o que a humanidade já conhece, passando pelo crivo da relevância, essa associada a determinados valores tornados prioritários, o coletivo estará em melhores condições de avaliar se há a necessidade de pesquisas novas, inéditas. Se a extensão constitui ponto de partida, não necessariamente a pesquisa constitui ponto de chegada. Esse está no possível enfrentamento do problema demandado. Constatada a necessidade de pesquisa inédita, no andamento dessa, há constantes retornos ao ensino. Ensino como a busca coletiva, a pesquisa bibliográfica ou uma aula expositiva sobre algo já conhecido, mas não trabalhado antes de iniciar a pesquisa inédita.

\section{Em busca de agriculturas em harmonia com a natureza}

Yo voy soñando caminos ${ }^{10}$

A teorização alcançada, descrita anteriormente, esteve alicerçada em práxis, pontuais, desenvolvidas no espaço da educação formal. A partir de 2014 ganha materialidade em projeto sediado na Pró-Reitoria de Extensão de Universidade Federal brasileira. Projeto constituído de uma incubadora social, guarda-chuva de nove subprojetos. Nesses, a dinâmica teórico-metodológica extensão-ensino-pesquisa passa a ter uma efetividade maior. Um desses, relacionado à produção de alimentos segundo princípios da agroecologia, constitui foco do presente trabalho.

No início do artigo foi destacado que, pelo cenário tendencial atual, o fazer pesquisa poderá ocorrer num mundo bastante distinto daquele que, hoje, tem sido foco das mesmas. Tendências não significam determinismos. Apesar das mesmas, o futuro está em aberto. Sua construção depende da ação humana. Um mundo "menos feio, menos malvado, mais justo", como dizia Freire, não tendencial nesse momento, depende da entrada em cena dos, até agora, excluídos de participar da construção da história. Um futuro em que não prospere a necropolítica, o necroliberalismo. Nesse futuro incerto, algo é absolutamente central: somente haverá qualidade de vida se dispusermos de alimentos de qualidade. Qualidade de vida, para além da dimensão biológica, impossível num cenário de degradação socioambiental. Degradação intrínseca à lógica da agricultura

10 Antônio Machado, poeta espanhol. 
industrial capitalista, agora denominada de convencional. Nesse sentido, a caminhada em processo busca essa qualidade de vida, para todos(as), iluminada por teorização em curso.

A referida modernização da agricultura, o que significou a efetiva instalação do capitalismo no campo, não apenas no Chile, mas um fenômeno planetário, com modificações socioambientais profundas e degradantes, não foi um mero acidente de percurso, um mau uso da CT (tecnociência capitalista), das forças produtivas capitalistas. Os formuladores da revolução verde, mesmo com elementos mais altruístas presentes, não distribuíram sementes das quais pudessem germinar modelos socioeconômicos distintos do capitalismo. Seus pacotes continham (hoje atualizados, por exemplo, com a clonagem e a transgenia) sementes nas quais estavam projetadas características das quais jamais brotaria um modelo de agricultura não funcional ao capital.

Dentre os muitos problemas que têm sido apontados como vinculados ao modelo de agricultura industrial, a padronização, a lógica monocultural, gerando uma significativa redução da biodiversidade, degradando ecossistemas, sintetiza a insustentabilidade desse modelo. Também, proximamente inviável porque movido por algo finito: os combustíveis fósseis. Hoje, alcançou-se a compreensão de que a diversidade (biodiversidade) representa uma barreira à propagação de doenças, vírus.... Contrariamente, a padronização, exemplificada pelas monoculturas, com grandes confinamentos de aves, suínos..., representa "caminho livre", um corredor para a propagação das mesmas. Esse constitui um dos fundamentos para a, cada vez mais, exitosa implementação de agroflorestas. Progressivamente cresce a compreensão de que há uma relação entre a produção de doenças pela modernização capitalista e a destruição da natureza (Silva, 2021, p. 5).

$\mathrm{Na}$ indústria, na configuração de currículos escolares e, por último, no campo, rompe-se um longo processo coevolutivo entre mãos e cérebro. Nesses âmbitos, criouse dualidades funcionais ao capital. Cérebro e mãos/braços, conceber e executar, pensar e agir, humano e natural.... Ao interromper o longo processo evolutivo, ocorrido sem essas dualidades, criou-se ambientes artificiais que desconsideram o mundo natural, os ciclos naturais, o processo entrópico. Essa artificialização, como a agricultura industrial, com a desconsideração dos ciclos naturais, das condições edafoclimáticas, do aprendizado resultante dessa coevolução, cria algo como um "mundo paralelo", o qual não está em sintonia com a natureza. Desarmonia constituindo o substrato da crescente degradação socioambiental ${ }^{11}$. Esse "mundo paralelo" à dinâmica de funcionamento da natureza somente se sustenta enquanto houver disponibilidade de combustíveis fósseis e/ou enquanto as mudanças climáticas não o inviabilizarem.

A lógica industrial, que não está apartada da lógica de acumulação de capital, estava lá nas "ingênuas" sementes presentes nos pacotes da revolução verde. Assim, o

11 Não há consciência ambiental que reverta esse processo, conforme analisado em Auler e Auler (2015) e Auler (2018). 
capitalismo instala-se no campo. Passamos da "agri-cultura" para o "agro-negócio"12 . A agri-cultura, voltada ao valor uso (necessidades humanas) é substituída pela lógica do agro-negócio, um negócio voltado para o valor troca, no qual os alimentos são concebidos como mercadoria funcional à lógica de acumulação de capital. $\mathrm{O}$ discurso do agronegócio insiste na diferença entre atrasado e moderno, jamais numa contraposição de lógicas. No discurso do capital, assumido também por boa parte de grupos políticos de esquerda, seduzidos pelo desenvolvimento tecnológico capitalista, a agricultura camponesa é aquela que ainda não conseguiu ser "moderna", ou seja, capitalista.

Para Cechin (2010), o trabalho de Georgescu (1971; 1976), ao retirar o processo econômico do corpo da mecânica, dos processos reversíveis, conservativos e sem história, separado do ambiente natural, situando-o, apoiado em Prigogine (2009), como um processo aberto, dissipativo, tem implicações epistemológicas profundas. Sendo teorizado com premissas do modelo mecânico, esse modelo não dá conta da mudança qualitativa da matéria e energia que entram e saem do mesmo. A conclusão de Georgescu, considerando sua análise em novas premissas, é de que há limites termodinâmicos ao modelo de desenvolvimento econômico em curso, o que inclui a agricultura industrial.

Com a revolução industrial, o processamento para a obtenção de energia mecânica sofreu uma transformação significativa. Passou de endossomática (uso de músculos humanos e de animais) para exossomática (externa aos organismos vivos: máquina a vapor, motor de combustão interna $)^{13}$. No processo, quantidades crescentes de energia estão sendo utilizadas e degradadas. No processamento endossomático, utiliza-se fontes renováveis, basicamente a energia solar que, mediante processo fotossintético, é armazenada nas moléculas orgânicas. No exossomático, simplificadamente, o processo de liberação de energia não mais é processado no interior dos corpos de seres vivos, passando para a combustão (motores de combustão interna), cada vez menos, podendo ser abastecido por fontes renováveis. Esse último processo recorreu, primeiro ao carvão vegetal, em seguida, ao mineral e, depois, até hoje, aos denominados combustíveis fósseis principalmente petróleo.

É usual atribuir vantagens à agroecologia considerando que é pouco dependente de insumos externos. Cuidado! A produção pautada em princípios agroecológicos é pouco dependente dos insumos limitados, não renováveis (combustíveis fósseis). Mas é altamente dependente de um insumo externo ao próprio planeta terra: A radiação (energia) solar. Insumo ilimitado por um período de tempo de muitas gerações. Esse constitui um diferencial central entre modelos agroecológicos e a agricultura convencional. Modelos pautados na agroecologia, além de atenderem ao critério predominantemente economicista de sustentabilidade, formulado pelo relatório

12 Cechin (2010) chama a atenção para o progressivo desaparecimento dos denominados serviços gratuitos da natureza: resiliência dos ecossistemas, dinâmica de funcionamento dos ecossistemas e a polinização realizada pelas abelhas. Em relação à extinção das abelhas, problema particularmente grave, nos últimos anos, no RS, há uma obra recente de Rossi et al. (2020), com prólogos de Vandana Shiva e Rubens Onofre Nodari, com evidências dos impactos dos agrotóxicos sobre as abelhas.

13 Da combustão de um barril de petróleo resulta energia equivalente a 25.000 horas de trabalho humano. (Taibo, 2019). 
Burtland, não exaurindo os recursos terrestres, possibilitando a reprodução material das gerações futuras, ao degradar menos matéria e energia disponível no planeta, gerando menos resíduos, menos degradação socioambiental, lega às gerações presentes e futuras uma qualidade de vida superior ao modelo industrial/convencional. Esse horizonte é desafiador, dependente de decisões políticas e técnicas.

Interessante como contradições, inerentes à lógica capitalista, são silenciadas. $\mathrm{O}$ equilíbrio das contas, particularmente das contas públicas, sempre é apresentado como um dogma inquestionável. Um possível não equilíbrio das contas sempre é utilizado como justificativa para os problemas existentes, para cortes na área social. Porém, o orçamento, no campo energético, sob o capitalismo e a sua agricultura industrial é altamente deficitário. O “orçamento solar", a energia solar captável, é absolutamente insuficiente para sustentar esse modelo perdulário. Está constantemente retirando da poupança. Poupança, aqui, entendida como a energia solar estocada por um longo período de tempo (combustíveis fósseis). Em algum momento, a poupança, esse "brinde da natureza" como o capital a chama, acabará. E então? Não esperemos, apesar de não ser a opção do capital, para lutar por caminhos iluminados pelo orçamento solar, como a agroecologia.

A agroecologia, na qual a diversidade (biológica e cultural) constitui dimensão fundante, também, em suas várias caracterizações, é diversa. Diversas mas não excludentes. Sim complementares. Distintos autores situam-na como ciência, como prática agrícola, como movimento social. Por exemplo, Pupo (2009) destaca a natureza acadêmico-científica da agroecologia, em interface com as dimensões de movimento social e de prática agrícola.

Enquanto ciência, caracterizada como um conjunto de princípios que sustentam a transição para modelos de agricultura mais sustentáveis (Caporal et al., 2009; Altieri, 2012). Gusmán (2000) caracteriza-a como uma reorientação da coevolução interrompida entre a dimensão natural e cultural. Esse autor destaca outro elemento importante: a agroecologia necessita de uma interação orgânica com movimentos sociais, considerando que, sem isso, corre o risco de ser cooptada e esvaziada em seus princípios pela lógica do capital. Processo em curso, por exemplo, no campo da denominada produção orgânica, na qual grandes corporações transnacionais estão investindo.

A agroecologia não se baseia em receitas, mas sim em princípios, com universalidade, que são utilizados de forma diferente em realidades distintas. (Rosset, 2017, pp. 84-85). Quais são esses princípios: eliminar agrotóxicos e transgênicos; implementar práticas de conservação da água e do solo; recuperar e multiplicar as sementes nativas e as raças de animais locais; maximizar a matéria orgânica ea vida do solo; projetar o sistema para maximizar a reciclagem de nutrientes; eliminar a monocultura e diversificar o agroecossistema; fortalecer o tecido de organização social como meio de cultura para a agroecologia; promover a ação coletiva, a transição agroecológica e o efeito multiplicador; equidade agrária; protagonismo, autonomia e autossuficiência locais; diálogo de saberes e a investigação participativa; economia solidária e mercados 
justos e orgânicos; conservação da biodiversidade e soberania alimentar. (Rosset, 2017 e Caporal et al., 2009)

Se, até recentemente, e ainda hoje, conjunto significativo de integrantes de movimentos sociais engajados na transformação, o que inclui intelectuais do campo da esquerda, eram refratários ao campo da agroecologia, endossando a compreensão do máximo desenvolvimento das forças produtivas capitalistas, com um desenvolvimento científico-tecnológico atrelado à biotecnologia do agronegócio, cada vez mais, surgem engajamentos nesse campo. Por exemplo, João Pedro Stédile, coordenador nacional do MST, em fala proferida em evento sobre economia solidária, ocorrido em 2014, em Santa Maria-RS, destacou: "Precisamos de uma outra matriz produtiva e tecnológica".

Taibo (2019) e Durán e Reyes (2018) concluem, apoiados em exaustivas análises da literatura sobre o tema, que há significativos indicativos, mantidas as atuais tendências, de um colapso, entre 2020 e 2050, do sistema industrial capitalista. Como causas principais apontam dois aspectos distintos e complementares ligados aos combustíveis fósseis: sua presença e sua ausência. Presença que tornou possível o gigantismo e a complexidade desse sistema. Presença, de cuja combustão resulta um dos principais causadores $\left(\mathrm{CO}_{2}\right)$ das mudanças climáticas. Ausência que irá fazê-lo parar por falta de energia. Mudanças climáticas/degradação socioambiental e escassez de energia são apontadas como as principais causas desse provável colapso.

Para os autores, um dos campos em que essa insustentabilidade poderá manifestar-se intensamente é no modelo industrial de agricultura. Imaginemos que, num período não muito longo, essa agricultura deixe de receber qualquer aporte em termos de combustíveis fósseis. O que sobraria em termos de produção de alimentos? Qual seria a funcionalidade de todos esses equipamentos agrícolas que a movem hoje?

Uma antecipação, em pequena escala, do que poderá ocorrer em escala planetária aconteceu e continua acontecendo em Cuba desde o fim (colapso) da ex-URSS. Num processo ainda em curso, esse "colapso" teve reflexos na agricultura. Cuba, a exemplo da URSS, havia optado pelo modelo industrial de agricultura. Em Cuba, sem insumos externos oriundos dos combustíveis fósseis, antes vindos da URSS, esse modelo ficou muito fragilizado. O país tomou o caminho da agroecologia. Hoje, metade dos(as) camponeses(as) do país dedicam-se à agricultura agroecológica. (Rosset, 2017).

A mecanização, não apenas na agricultura industrial, a qual aumentou a produção e facilitou a distribuição, está a caminho de se tornar, por ser insustentável, uma enorme fonte de problemas. O mesmo pode ser dito da dependência que muitos camponeses têm em relação a sementes, fertilizantes, pesticidas, herbicidas e alimentos para animais. Um cenário marcado pelas monoculturas. Esse constitui, hoje, retrato da insustentabilidade, do caráter antiecológico da revolução verde e seus desdobramentos. (Taibo, 2019, p. 84).

Taibo (2019), na obra Colapso: Capitalismo terminal, transição ecossocial, ecofascismo, assim como obra de Durán e Reyes (2018), analisam dois cenários tendenciais para o durante e o pós colapso: a transição ecossocial e o ecofascismo. O ecofascismo constitui a cristalização de uma sociedade pautada na intensificação de 
valores associados ao egoísmo, com manifestações como competição, individualismo... Tem como pressuposto implícito a compreensão de que, para encarar de maneira eficiente o problema geral da escassez, não resta outro horizonte senão propiciar uma rápida e contundente diminuição no número de seres humanos que povoam o planeta.

Se a transição ecossocial ou algo próximo dela for o caminho durante e no pós-colapso, a maioria dos vestígios do capitalismo desaparecerá. Nesse cenário, contrariamente ao individualismo extremo, que poderá ser a marca do ecofascismo, podem reaparecer projetos de cunho coletivista ou socialista. No campo da educação, muita coisa do currículo atual deixará de ter utilidade. Deixará de estar voltado para a "formação de escravos da sociedade industrial", para a legitimação de hierarquias e desigualdades, para o estímulo à competição, à geração de consumidores acríticos e de pessoas passivas e dóceis. Considerando necessidades vitais, como a necessidade de produzir a própria comida, haverá de estar voltada para problemas reais: poucas pessoas sabem como construir uma casa ou como trabalhar no campo. Nesse cenário, a revalorização do papel dos anciãos será fundamental. (Taibo, 2018). Continua a análise do autor,

Aos poucos, se tornará evidente a insustentabilidade da agricultura tecnológica e mercantilizada, muito dependente de subvenções, fertilizantes e maquinaria, imersa no emprego intensivo do petróleo, lastreada pela monocultura e empenhada na comercialização dos produtos em lugares distantes. (Taibo, 2018, p. 117)

Sintetizando, para os autores, os movimentos que anteciparmos, as sementes que lançarmos poderão contribuir para a configuração do cenário que, hoje, não se apresenta como tendencial: a transição ecossocial. Não estaremos sentados esperando que o colapso ocorra. Mas, considerando esse cenário tendencial, talvez a luta política dos oprimidos seja insuficiente para construir esse outro mundo antes do colapso. Colapso já, hoje, constituindo o cotidiano de grande parte da população planetária. Tudo o que fizermos, agora, os movimentos que anteciparmos, as sementes que lançarmos poderão constituir o diferencial em ambos os casos.

\section{Do diálogo ao diálogo de saberes}

Em 2014, um grupo de agricultores(as) agroecológicos, assentados do MST, juntamente com técnicos da Empresa de Assistência Técnica e Extensão Rural (EMATER), procura a Pró-Reitoria de Extensão da referida Universidade Federal para o estabelecimento de parcerias. Parcerias em processos produtivos e educativos ${ }^{14}$. Intuiuse, naquele momento, que a teorização extensão-ensino-pesquisa poderia, além de iluminar uma caminhada promissora, ser foco de aprofundamento. Foi o início de uma

14 É significativa a fala de um agricultor que relatou mais ou menos o seguinte: Nossa escola, situada num assentamento do MST, defende que nossos filhos tenham aulas de informática para que possam encontrar empregos nas grandes fazendas. Desapontado mas não resignado, concluiu: foram anos de lutas para sair, para romper com a lógica patrão-empregado das fazendas e, agora, querem preparar nossos filhos para voltar à mesma. 
caminhada em que professores, servidores e estudantes dessa Universidade colocaramse ao lado de sujeitos sufocados, oprimidos.

O reprojetamento de uma incubadora social ${ }^{15}$ teve, nessa demanda, nesse coletivo ponto de partida. Projetando novos horizontes, parte daquilo que foi abandonado pelo caminho: demandas, necessidades, conhecimentos e práticas de sujeitos vulnerabilizados, abandonados pelo sistema dominante. Coerente com o corpo teórico assumido, o projeto busca superar a concepção propedêutica em que primeiro o sujeito aprende, forma-se, para, depois, trabalhar, produzir e gerar renda. Essa lógica não é viável para sujeitos vulnerabilizados. Formar-se, aprender, deve vir acompanhado de processos de trabalho e renda. Produção e aprendizagem não podem estar separadas em termos espaço-temporais. Esse projeto foi constituído por nove subprojetos. Num segundo momento, o foco principal passa a ser aquele relacionado aos princípios da agroecologia, denominado de Grupo de Agricultores Orgânicos da Região Central do Rio Grande do Sul.

O projeto da incubadora inaugurou uma nova forma de relacionamento entre universidade e sociedade. $\mathrm{O}$ ponto de partida está na extensão, na comunidade. $\mathrm{Ou}$ seja, as demandas que foram submetidos ao edital de seleção ${ }^{16}$ deveriam atender a uma exigência central: estruturados em torno de problemas demandados pela comunidade. Problemas a serem transformados em problemas de conhecimento, em problemas de pesquisa.

Também, cada coordenador dos nove subprojetos, no decorrer de sua execução (03 anos), comprometeu-se a organizar e oferecer, juntamente com a equipe do projeto, pelo menos uma Disciplina Complementar de Graduação (DCG) para estudantes de graduação, a qual deveria assumir um caráter multidisciplinar. Com os nove projetos ${ }^{17}$ em andamento ${ }^{18}$, meu olhar mais sistemático passa a estar centrado naquele relacionado à agroecologia, constituído por agricultores(as) sufocadas, oprimidas pela lógica do agronegócio. Foi nesse âmbito que amadureceu a amplificação da categoria diálogo para diálogo de saberes.

Se, do encontro entre Freire e o PLACTS avançou-se no diálogo entre processos produtivos e educativos, foi, nesse projeto, com elementos oriundos dessa práxis, que

15 http://w3.ufsm.br/pre/images/pdfs/RegimentoIncubadora.PDF.

16 Edital de abertura de inscrições de projetos para a Incubadora Social da UFSM. http://w3.ufsm.br/pre/images/ EDITAL_01-2016_INCUBADORA_SOCIAL.pdf

17 Ará dudu - Coletivo de arte e cultura negra; Marias Bonitas fazendo história; Ketyjug Tegtu \& Guaviraty Porã (Projeto conjunto de duas etnias indígenas: Guarani e Kaingang); Associação de catadores de materiais recicláveis Palmeira Verde; Grupo de agricultores orgânicos de região central do RS; Nível 8 - Mulheres na construção civil; Associação comunitária remanescentes de quilombo Júlio Borges; Associação Quilombola Linha Fão e CORAP — Coletivo de resistência artística periférica.

18 Para cada projeto foi constituído um coletivo multidisciplinar (incluindo a comunidade demandante) responsável pela execução. O total de envolvidos, no conjunto dos projetos, aproximadamente: professores da Universidade (em torno de 20: metade desses envolvidos no colegiado gestor da incubadora), servidores da mesma, estudantes bolsistas, mestrandos e doutorandos, entidades externas à Universidade, como a EMATER e os protagonistas: em torno de 400 membros das comunidades que demandaram os 10 (Efetivamente, nove projetos estão em execução. Um coletivo autodissolveu-se) projetos. A execução dos projetos teve início em junho de 2017, estando sua conclusão, inicialmente, prevista para agosto de 2020. Considerando o surgimento da pandemia (COVID-19) seu término foi prorrogado para maio de 2021. 
a categoria freireana diálogo precisou ser alargada ainda mais. $\mathrm{Na}$ agroecologia, não existem modelos a serem seguidos. Existem princípios gerais, com universalidade, cuja tradução em práticas efetivas está na dependência de elementos mais locais, como condições do clima e solo, de elementos culturais e históricos. Daquilo que tem sido denominado de memória biocultural. Essa carrega a história da coevolução ocorrida entre o mundo natural e o mundo social. Contém a memória sobre como distintas populações, em distintas regiões, aprenderam a conviver com as adversidades naturais e a tirar proveito das características locais. Memória biocultural como dimensão importante para que a humanidade chegasse onde chegou. Assim como indivíduos e povos, a espécie humana também tem memória. Essa permite desvelar as relações que a humanidade tem estabelecido com a natureza, suporte e referência de sua existência ao longo da história (Toledo \& Barrera-Bassols, 2015). Há autores que conceituam a agroecologia como o reconectar da coevolução interrompida entre o mundo natural e social, ocorrida no processo de artificialização da agricultura industrial. Reconexão considerada fundamental para que possamos alcançar uma efetiva sustentabilidade socioambiental.

Se, antes, a categoria diálogo havia sido ampliada para diálogo entre processos produtivos e educativos, com o processo em curso, com a análise de literatura sobre agroecologia, com teorizações subjacentes, foi-se aprofundando a compreensão da necessidade do alargamento dessa categoria. Chegou-se no diálogo de saberes, dinâmica central em processos agroecológicos. Mas quem faz parte do mesmo? Quais saberes estão em diálogo? Com a aproximação entre Freire e o PLACTS chegou-se à compreensão de que, para além dos conhecimentos produzidos pela humanidade, a denominada cultura elaborada (Snyders, 1988), também há a necessidade de conhecimentos inéditos oriundos do enfrentamento de demandas negligenciadas historicamente.

Agora, um novo campo passa a integrar a categoria diálogo: o campo da memória biocultural. Assim, o processo em análise pode ser sintetizado como uma ampliação da categoria diálogo de Freire: de diálogo para diálogo de saberes. Esse constituído de três campos em diálogo: a cultura elaborada, conhecimentos inéditos que se revelarem necessários e a memória biocultural. Os dois últimos, por não serem funcionais à lógica do capital, somente entram em cena mediante movimentos contra-hegemônicos.

No enfoque agroecológico, há poucos processos ou problemas que não sejam portadores de complexidade. Assim, os conhecimentos e práticas, presentes em cada um desses três campos, atuam como luzes que iluminam as diferentes faces dessa complexidade. Não se busca um denominador comum entre os mesmos. $\mathrm{Na}$ aproximação Freire-PLACTS concluiu-se que, por falta de luzes, permaneciam zonas de escuridão. Escuridão a ser iluminada com a produção de conhecimentos inéditos. Agora, novamente, identificou-se zonas escuras na efetivação dos princípios da agroecologia. As luzes faltantes foram encontradas na memória biocultural.

Em Freire, no trabalho com temas geradores, na realização da redução temática, eram buscados conhecimentos disciplinares constituintes da cultura elaborada. Ou seja, 
Feita a delimitação temática, caberá a cada especialista, dentro de seu campo, apresentar à equipe interdisciplinar o projeto de "redução" de seu tema. No processo de "redução" deste, o especialista busca os seus núcleos fundamentais que, constituindo-se em unidades de aprendizagem e estabelecendo uma sequência entre si, dão a visão geral do tema 'reduzido'. (Freire, 1987, p. 66)

Passando pelo PLACTS, agregou-se os conhecimentos inéditos resultantes do enfrentamento de demandas negligenciadas historicamente. Agora, no diálogo entre processos produtivos e educativos, presentes no campo da agroecologia, entrou a memória biocultural. Tem-se três campos de conhecimento participantes do diálogo. Não se trata de um vale tudo. Quais os parâmetros, critérios que balizam seletividades? A resolução de problemas, o encaminhamento de práticas é pautado pelos princípios da agroecologia, princípios associados a determinados valores. O guia, o filtro são esses princípios/valores. Nesse sentido, a categoria diálogo, agora diálogo de saberes, não pode ser desvinculada da categoria, também freireana, problematização. Problematização necessariamente incidindo sobre esses três campos. Não parece razoável esperar que, por exemplo, o conjunto das pessoas envolvidas com agroecologia esteja em condições de problematizar a consistência interna da cultura elaborada. Contudo, considerando os critérios, os filtros colocados, está em condições de participar da avaliação quanto a efetiva relevância ou não de determinado conhecimento em termos dos reais problemas colocados. Assim como das consequências decorrentes das seletividades adotadas.

Voltando à incompletude, no corpo teórico freireano, anteriormente discutida. Esse autor foi pioneiro, com a atribuição de determinado significado e intencionalidade, na fundamentação e na prática com a categoria diálogo. Diálogo sempre associado à problematização. Mesmo não lhe atribuindo a amplitude assumida no campo da agroecologia, a gênese do diálogo de saberes parece ser encontrável em Freire. Concordaria Freire com essa amplificação?

Diálogo, para Freire, não tem o significado de uma conversa informal, de conversar sobre qualquer coisa, de um bate-papo sobre questões corriqueiras. Significa um diálogo problematizador entre os conhecimentos do educando e os do educador sobre o mundo vivido. Mundo expresso, em situações pedagógicas, através do que denominou de temas geradores. Temas que carregam, para o interior de processos educativos, manifestações locais de contradições sociais mais amplas. Ao afirmar que ninguém sabe tudo e que ninguém ignora tudo, ao defender o diálogo entre saberes distintos sobre problemas vividos, está, no meu entender, lançando as bases para a fundamentação do que veio a ser denominado de diálogo de saberes.

Processos educativos, propostas curriculares inspiradas no referencial freireano estão entre as que, no meu entender, mais avançaram na compatibilização entre o uso de conhecimentos produzidos, em geral demandados por fenômenos simples, conforme análise de Prigogine (2009), para a compreensão de temáticas, de processos mais complexos. Algo constantemente negligenciado: Freire não embasava seus pressupostos na compreensão de um professor(a) mediador(a) como ocorre em vários outros 
referenciais. Para ele, o mediador do diálogo entre educando e educador é o mundo vivido. Ou seja, os temas geradores, extraídos desse mundo, constituem o centro em torno do qual ocorre o diálogo entre os conhecimentos do educador e os dos educandos.

Explicitamente ou implicitamente, em Freire, está presente a compreensão da complexidade de muitos desses temas. Não propõe a constituição de novos corpos teóricos a partir do diálogo entre conhecimentos disciplinares disponíveis. Esses são concebidos como luzes que iluminam as várias faces, ou então, as várias dimensões ou variáveis presentes em problemas complexos. As disciplinas têm uma função mais instrumental: iluminar. Contudo, conforme argumentação desenvolvida ao longo deste artigo, em Freire, assim como em propostas curriculares inspiradas nesse referencial, muitas vezes, as luzes têm se limitado aos conhecimentos historicamente produzidos e presentes nos currículos convencionais.

No âmbito do referencial freireano, segue-se, em linhas gerais, com o seguinte encaminhamento: investiga-se o tema, o tema gerador e, na quarta etapa, denominada de redução temática (nessa há lacunas/incompletudes em Freire), são selecionados conhecimentos científicos, conhecimentos disciplinares para fazer o programa, para entender o tema/problema e, se possível, buscar soluções. A metáfora de um reservatório contribui para aprofundar essa discussão. Tem-se disponível um grande reservatório, contendo conhecimentos científicos, disciplinares, cultura elaborada, conhecimentos universais. Assim, identificado o tema gerador, vai-se ao reservatório e seleciona-se o que é necessário para entender a realidade.

Problema: O que entrou nesse reservatório? Aquilo que foi chancelado pela academia. Aquilo que foi pesquisado, comprovado, chancelado. E o que a academia basicamente pesquisa: as demandas do capital. Física nuclear, Ciência-Tecnologia voltada para o agronegócio, revolução verde, nanotecnologia, praticamente nada ligado à agroecologia, à medicina social/preventiva, aproveitamento da energia solar, insustentabilidade do agronegócio ${ }^{19}$. Isso não significa que, na agroecologia, você vai descartar/ignorar esses conhecimentos. Por exemplo, leis da termodinâmica, fotossíntese, interação da radiação com a matéria, dentre outros. Esse reservatório contém conhecimentos e práticas necessárias e funcionais, por exemplo, para um modelo de agricultura pautado no agronegócio. Mas insuficiente e nem todos funcionais para uma agricultura pautada nos princípios da agroecologia. Em termos mais amplos, nesse reservatório, faltam coisas (há incompletudes) necessárias para uma transformação da realidade para além da moldura do capital.

$\mathrm{Na}$ práxis focalizada em termos reflexivos, o que faltava no reservatório? Por exemplo, a Teoria da Trofobiose ${ }^{20}$, uso do pó de rocha como fertilizante, influência da

19 A ciência demandada pelo agronegócio não pode continuar pautando, por exemplo, currículos de educação do campo. É ela que está no reservatório. Contudo precisamos conhecer o que está nesse reservatório para problematizá-lo.

20 Segundo a Teoria da Trofobiose, de Chaboussou (1999), plantas mais sadias e com menos estresse (químico, climático, etc...) serão mais resistentes a doenças e pragas. Ao contrário, a presença de aminoácidos livres na seiva das plantas, resultam em alimentos atrativos para ácaros, insetos, fungos ou vírus. Segundo Chaboussou, isto se deve ao fato de que "estes organismos, devido a seu equipamento enzimático, exigem alimentar-se de substâncias solúveis (aminoácidos livres), as únicas capazes de assimilar". Esses aminoácidos livres são produzidos quando são aplicados agrotóxicos, NPK... 
lua nas plantações, condições do clima e solo do local em que os agricultores produzem, sementes adaptadas a essas condições. Quais são os valores que acompanham o que está dentro do reservatório? Quais estão ausentes?

Também, conforme destacado em Auler (2018), quando surgiram os temas Os agrotóxicos e mais recentemente, os transgênicos/nanotecnologia causam danos para nós e aos ecossistemas?, onde buscar cultura elaborada? Em síntese, quando se faz a redução temática, quais conhecimentos disciplinares são selecionados? Basicamente aqueles que já estão no currículo. São conhecimentos que estão nesse reservatório, demandados pelo capital. Se as demandas, as necessidades dos oprimidos, dos excluídos tivessem sido pesquisadas, teríamos coisas mais interessantes, mais relevantes para os mesmos dentro desse reservatório. Possivelmente muito mais conhecimentos ligados aos princípios defendidos pela agroecologia. Por exemplo, não é possível pensar a agroecologia dentro dos paradigmas epistemológicos da ciência dos fenômenos simples, reversíveis no tempo. Nessa está presente a complexidade, a irreversibilidade. O fenômeno sofre modificações ao longo do processo. Dentro desse reservatório não há conhecimentos ligados à história, a aspectos culturais dos produtores(as). Não está a memória biocultural ${ }^{21}$.

Como justificar a entrada da memória biocultural no currículo, como conhecimento de valor? Parece que entramos numa armadilha, num círculo vicioso: aquele conhecimento produzido em coevolução entre humanos e natureza e que permitiu que a humanidade chegasse onde chegou, não é digno, por não ter passado pela chancela da academia, de figurar no currículo.

Sem esse conhecimento, sem o engajamento de agricultores(as), a feira orgânica, que ocorre semanalmente, no Campus da referida Universidade Federal, desde setembro de 2017, não teria sido efetivada. Espaço da feira muito mais que um espaço de comercialização, um espaço de diálogo de saberes envolvendo produtores(as), consumidores, estudantes, professores(as), EMATER. Espaço-tempo de produção de conhecimento, espaço-tempo de produção de aprendizagens. Espaço-tempo de problematização de mito que interessa à lógica do agronegócio: Não é mais possível produzir sem venenos/agrotóxicos.

Como fazer a redução temática se, na investigação temática, for identificado um tema, uma demanda historicamente silenciada, negligenciada, não transformada em problema de pesquisa, não investigada? É possível fazer a redução temática em problemas inéditos como mudanças climáticas e degradação socioambiental sem precedentes, problemas complexos com muitas variáveis interagindo, variáveis do mundo natural, do mundo transformado pela ação humana, variáveis ligadas a aspectos socioeconômicos? Existe conhecimento para compreender e enfrentar um problema com variáveis de várias naturezas interagindo, um fenômeno não replicável em laboratório, nos quais, em geral, a memória biocultural é desprezada? Não são necessários conhecimentos e práticas inéditas, talvez essenciais para que nós humanos não desapareçamos da face da terra?

21 Nas palavras de um campesino, expressando o longo processo de coevolução das sementes com elementos culturais e edafoclimáticos, "a semente expressa a memória do meu povo". Em outras palavras, a memória biocultural. 
Parece razoável supor que, com muitas demandas não pesquisadas, historicamente silenciadas porque situadas entre os excluídos e/ou não funcionais à lógica do capital, continuem sem respostas, sem a possibilidade de fazer a redução temática. Uma outra situação: existem conhecimentos, ainda que bastante precários, mas esses não mais são de domínio público. Se antes, com uma razoável separação entre ciência e tecnologia, sendo a ciência publicada, socializada e a tecnologia patenteada, hoje, estando imbricadas, no âmbito da tecnociência capitalista, tudo passa a ser protegido por sigilo. Estão disponíveis, já sendo trabalhados em aulas de Biologia, conhecimentos e técnicas utilizadas na produção de um organismo geneticamente modificado. Contudo desconheço literatura, cultura elaborada publicada sobre estudos conclusivos quanto à segurança, quanto aos efeitos, às consequências dos transgênicos sobre meu organismo e sobre os ecossistemas (o mesmo vale para a nanotecnologia). Parece que a nossa segurança não vai muito além de atos de fé. Atos de fé nos estudos das próprias empresas que produzem esses produtos segundo o valor troca: gerar mais lucros.

Há outro aspecto em Freire associado às discussões anteriores. Em determinado momento de sua trajetória, de sua práxis educacional, ressaltou que havia presumido, equivocadamente, que o desenvolvimento da consciência crítica, necessariamente, faria com que as pessoas passassem a agir. Em suas palavras, "O meu equívoco consistiu em não ter tomado estes polos - conhecimento da realidade e transformação da realidade em sua dialeticidade. Era como se desvelar a realidade significasse a sua transformação." (Freire, 2009, p. 103). O que Freire constatou é que a consciência da realidade não garante sua transformação. Talvez houvesse uma situação-limite que o próprio Freire não identificou. Considerando que esse autor não aprofundou a reflexão epistemológica e sociológica do campo científico-tecnológico, talvez não tenha constatado que a realidade não é transformável, apenas, com uma agenda de pesquisa demandada pelos interesses dominantes, resultando conhecimentos, uma cultura elaborada sustentada em valores alinhados à preservação do status quo e não de sua superação. Esteve frágil, em Freire, a compreensão de que não é possível construir um outro mundo, menos feio, unicamente com os conhecimentos, com a cultura resultante do enfrentamento dos problemas escolhidos pelos interesses, pelos valores dos dominantes.

Sintetizando, apesar de Freire ter sido um dos que mais avançou em práxis sobre interdisciplinaridade, a metáfora do reservatório contribui para entender que faltam luzes para fazer a redução temática. Luzes e valores para transformar a realidade. Freire não aprofundou a compreensão de que, com aquilo que está no reservatório, talvez seja possível uma compreensão crítica da realidade, mas talvez não transformá-la para além da moldura do capital. Essa limitação consistiu de situação-limite na práxis freireana. Ele não aprofundou a necessidade de que, para sair da moldura capitalista, é necessário transformar o sistema produtivo. Transformação que resulte em novas sementes. Ou seja, a busca de conhecimentos e práticas inéditas. Para o diálogo de saberes, para a amplificação da categoria diálogo, o que está no reservatório é insuficiente. $\mathrm{Na}$ materialização dos princípios da agroecologia, na gestação de novas sementes, para além 
do tripé cultura produzida historicamente (aquela que se encontra no reservatório), conhecimentos inéditos e memória biocultural, outros/novos valores são fundamentais (luzes que faltam). Nesse processo, está sendo amplificado e diversificado o conteúdo desse reservatório. Está em curso um processo de produzir juntos e aprender juntos: coprodução e coaprendizagem.

\section{Considerações Finais: Coprodução e Coaprendizagem}

Ao invés de "considerações finais", a terminologia "considerações iniciais" seria mais adequada. Constituem considerações iniciais sobre duas categorias em processo de amadurecimento: coprodução e coaprendizagem. Categorias em constituição no contexto do diálogo de saberes. São sementes que incorporam, em processos de coevolução, as práxis relatadas e experienciadas descritas ao longo do texto. Constituem sementes de novos processos educativos. Sementes de processos produtivos e educativos em diálogo.

Freire, com sua obra, pretende colocar o oprimido no palco da história. Porém, com o conjunto das práxis analisadas e realizadas, identificou-se a denominada incompletude na mesma. Resumidamente, um olhar excessivamente generoso em relação à Ciência-Tecnologia capitalista, em relação a suas forças produtivas. Continua frágil em Freire, mesmo nos escritos mais recentes, a defesa da possibilidade e da necessidade de um desenvolvimento científico-tecnológico distinto daquele demandado pelo capital. Esse constitui o aspecto fulcral da incompletude identificada. Incompletude que começa a ser trabalhada por Delizoicov e Auler (2011) e Auler e Delizoicov (2015), com aprofundamento neste artigo.

A colocação dos oprimidos, no palco da história, pode ficar fragilizada se suas demandas não forem transformadas em problemas de conhecimento. Ou melhor, se suas demandas forem enfrentadas, unicamente, com os conhecimentos produzidos a partir das demandas dos opressores. Para Freire, a superação da cultura do silêncio, a problematização da cultura, dos valores opressores, hospedados na consciência dos oprimidos, é fundamental para que assumam a condição de sujeitos históricos. Contudo, o que esteve ausente, no espaço-tempo em que Freire atuou, é a compreensão de que os produtos científico-tecnológicos também "hospedam" valores. Valores internalizados no produto científico-tecnológico e omitidos. Valores não identificados para sua problematização. Esses produtos materializam características associadas a determinados interesses e valores. Valores funcionais à perpetuação do status quo. Nesse sentido, a transformação da realidade poderá ficar fragilizada.

"Transformação da realidade". O que significa isso? Para Freire, particularmente expresso em textos mais recentes, estava claro. Significa contestar o capitalismo e defender o socialismo. Em processos educativos tornou-se lugar comum defender a transformação da realidade. O capitalismo também a transforma. Transforma-a a tal ponto que há indicativos de que podemos estar na iminência de um colapso socioambiental. O que se postula consiste na necessidade de, para transformá-la, para além da moldura capitalista, 
dentre outros aspectos, um redirecionamento do desenvolvimento científico-tecnológico. Redirecionamento que tenha como ponto de partida as demandas dos oprimidos, demandas ignoradas porque não funcionais para o capital. Demandas transformadas em problemas de pesquisa, em problemas de conhecimento. O silenciamento, a não problematização dos valores funcionais ao capital, "hospedados" no produto científicotecnológico, constitui situação-limite em Freire, não captando o novo inédito-viável, expresso, por exemplo, no campo da agricultura, pela agroecologia.

Contudo, a robustez do corpo teórico freireano é tal que está constituído de elementos internos (investigação temática), articulados às proposições do PLACTS/ Dagnino, para superar incompletudes identificadas. A investigação temática permite a identificação de demandas historicamente negligenciadas, demandas geradoras de currículos (ensino), geradoras de problemas de pesquisa (pesquisa).

Esse encaminhamento teórico-metodológico ajudou a compreender que, no processo de superação da incompletude apontada, haveria a necessidade de ampliar a categoria diálogo para diálogo de saberes, o qual envolve a cultura elaborada, os conhecimentos e práticas inéditas, resultantes do enfrentamento de demandas historicamente negligenciadas e a memória biocultural. Desse processo, surgem duas novas categorias ainda incipientes, em processo de amadurecimento: coprodução e coaprendizagem, as quais, sinalizando novos horizontes para processos produtivos e educativos, nutrem-se do diálogo entre ambos. Diálogo entre agenda de pesquisa do oprimido e pedagogia do oprimido.

Sinalizações promissoras, quanto ao redimensionamento da universidade tendo em vista sua efetiva relevância social, comparecem na práxis desenvolvida. Começando pela extensão, passando pelo ensino e a pesquisa constitui caminho teórico-metodológico que possibilita o diálogo entre processos produtivos e educativos. Esse diálogo, ampliado para diálogo de saberes, sinaliza a pertinência das categorias, ainda incipientes, coprodução e coaprendizagem. E as decorrências desse diálogo de saberes para a educação em ciências? Para além desse âmbito, incluindo-o, processos educativos que se pautarem pela dinâmica teórico-metodológica assumida, assim como ocorreu, ainda de forma pontual, no funcionamento da universidade, necessitarão de um profundo redimensionamento, por exemplo, dos espaços educativos inspirados na linha de montagem da sociedade industrial capitalista. Implica num efetivo diálogo, que resulte em efetivas práxis, entre processos educativos considerados, a comunidade e a universidade, ou melhor, com setores dessa comprometidos com sua efetiva relevância para o conjunto da sociedade. Há a necessidade de um efetivo diálogo entre processos produtivos e educativos.

\section{Referências}

Altieri, M. (2012). Agroecologia: bases científicas para uma agricultura sustentável (3a ed.). Expressão Popular. 
Angotti, J. A. P. (1982). Solução Alternativa para a Formação de Professores de Ciências - um projeto educacional desnvolvido na Guine-Bissau (Dissertação de Mestrado, Universidade de São Paulo, São Paulo, São Paulo).

Angotti, J. A. \& Delizoicov, D. (1990). Física. Cortez.

Archanjo Junior, M. G. de \& Gehlen, S. T. (2020). A Tecnologia Social e sua contribuição para a Educação em Ciências. Revista Brasileira de Pesquisa em Educação em Ciências, 20(u), 345-374. https://doi.org/10.28976/1984-2686rbpec2020u345374

Auler, D. (2002). Interações entre Ciência-Tecnologia-Sociedade no Contexto da Formação de Professores de Ciências (Tese de doutorado, Universidade Federal de Santa Catarina, Florianópolis, Santa Catarina). Repositório Institucional da UFSC. http://repositorio. ufsc.br/xmlui/handle/123456789/82610

Auler, D. (2007). Enfoque Ciência-Tecnologia-Sociedade: pressupostos para o contexto brasileiro. Ciência \& Ensino, 1(número especial), 1-20.

Auler, D. (2018). Cuidado! Um cavalo viciado tende a voltar para o mesmo lugar. Appris. Auler, D., \& Delizoicov, D. (2006). Ciência-Tecnologia-Sociedade: relações estabelecidas por professores de ciências. Revista Electrónica de Enseñanza de las Ciencias, 5(2), 337355.

Auler, D., \& Delizoicov, D. (2015). Investigação de temas CTS no contexto do pensamento latino-americano. Linhas Críticas, 21(45), 275-296. https://doi.org/10.26512/ lc.v21i45.4525

Auler, N. M. F., \& Auler, D. (2015). Conceber e Executar Currículos: ampliando o processo formativo de educadores(as). In N. M. F. Auler \& D. Auler (Orgs.), Concepção e execução de currículo no processo formativo de Licenciandos do PIBID (pp. 13-42). CRV.

Braverman, H. (1987). Trabalho e capital monopolista: a degradação do trabalho no século $X X\left(3^{\text {a }}\right.$ ed.). LTC.

Brick, E. M., Pernambuco, M. M. C. A., Silva, A. F. G., \& Delizoicov, D. (2014). Paulo Freire: interfaces entre Ensino de Ciências Naturais e Educação do Campo. In M. C. Molina (Org.), Licenciaturas em Educação do Campo e o Ensino de Ciências Naturais: desafios à promoção do Trabalho Docente interdisciplinar (pp. 23-59). MDA.

Caldart, R. S. (2017). Trabalho, agroecologia e educação politécnica nas escolas do campo. In J. H. Pires, H. T. Novaes, A. Mazin \& J. Lopes (Orgs.), Questão agrária, cooperação e agroecologia, vol. III (pp. 1-33). Outras Expressões.

Caporal, F. R., Paulus, G., \& Costabeber, J. A. (2009). Agroecologia: uma ciência do campo da complexidade. Brasília.

Cechin, A. (2010). A natureza como limite da economia: a contribuição de Nicholas Georgescu-Roegen. Senac/Edusp.

Chaboussou, F. (1999). Plantas doentes pelo uso de agrotóxicos: a teoria da Trofobiose (2a ed.). L\&PM. 
Dagnino, R. P. (2008). Neutralidade da ciência e determinismo tecnológico: um debate sobre a tecnociência. Unicamp.

Dagnino, R. P. (2010a). Uma estória sobre Ciência e Tecnologia ou Começando pela extensão universitária. In R. P. Dagnino (Org.), Estudos Sociais da Ciência e Tecnologia \& Política de Ciência e Tecnologia: Alternativas para uma nova América Latina (pp. 293324). Eduepb.

Dagnino, R. P. (2010b). Um dilema latino-americano: ciência e tecnologia para a sociedade ou adequação sócio-técnica com o povo?. In R. P. Dagnino (Org.), Estudos Sociais da Ciência e Tecnologia \& Política de Ciência e Tecnologia: Alternativas para uma nova América Latina (pp. 265-292). Eduepb.

Dagnino, R. P. (2019). Tecnociência solidária: um manual estratégico. Lutas Anticapital. Delizoicov, D. (1980). Uma experiência em ensino de ciências na Guiné Bissau -Depoimento. Revista de Ensino de Física, 2(4), 57-72.

Delizoicov, D. (1982). Concepção problematizadora do ensino de ciências na educação formal (Dissertação de Mestrado, Universidade de São Paulo, São Paulo, São Paulo).

Delizoicov, D. (1991). Conhecimento, tensões e transições (Tese de Doutorado, Universidade de São Paulo, São Paulo, São Paulo).

Delizoicov, D., \& Auler, D. (2011). Ciência, Tecnologia e Formação Social do Espaço: questões sobre a não-neutralidade. Alexandria: Revista de Educação em Ciência e Tecnologia, 4(2), 247-273.

Delizoicov, N. C., Stuani, G. M., \& Delizoicov, D. (2013). Reorientação Curricular na Concepção Freiriana de Educação: análises em dissertações. Revista e-Curriculum, 3(11), 684-712.

Durán, R. F., \& Reyes, L. G. (2018). En la espiral de la energía. Volumen II: Colapso del capitalismo global y civilizatorio ( $2^{\text {a }}$ ed.). Libros en Acción.

Freire, P. (1981). Ação cultural para a liberdade (5a ed.). Paz e Terra.

Freire, P. (1987). Pedagogia do Oprimido (28 a ed.). Paz e Terra.

Freire, P. (1995a). Educação na cidade. Cortez.

Freire, P. (1995b). À sombra desta mangueira. Olho d'água.

Freire, P. (1996). Pedagogia da Autonomia: saberes necessários a prática educativa (6a ed.). Paz e Terra.

Freire, P. (2002). Extensão ou comunicação? (12a ed.). Paz e Terra.

Freire, P. (2009). Pedagogia da Esperança: um reencontro com a pedagogia do oprimido (16 ed.). Paz e Terra.

Georgescu-Roegen, N. (1971). The entropy law and the economin process. Harvard University. 
Georgescu-Roegen, N. (1976). Energy and Economic Myths. Pergamon Press.

Guzmán, E. S. (2000). Agroecología y desarrollo rural sustentable: una propuesta desde Latino América. [Manuscrito não publicado].

Herrera, A. O. (1971). Ciencia y Política en América Latina (8 aed.). Siglo XXI.

Herrera, A. O. (1973). Los determinantes sociales de la política científica en América latina. Política científica explícita y política científica implícita. Revista de Ciências Sociais, 13(49), 98-112.

Kuhn, T. (1998). A estrutura das revoluções científicas ( $5^{\mathrm{a}}$ ed.). Perspectiva.

Lacey, H. (2008). Valores e atividade científica 1. Editora 34.

Muenchen, C. (2010). A disseminação dos três momentos pedagógicos: um estudo sobre práticas docentes na região de Santa Maria/RS (Tese de doutorado, Universidade Federal de Santa Catarina, Florianópolis, Santa Catarina). Repositório Institucional da UFSC. http://repositorio.ufsc.br/xmlui/handle/123456789/93822

Mundaca, R. (6 de junho, 2015). El modelo convencional de producir alimentos en Chile y de la ausencia de políticas de desarrollo agrícola. Mapuexpress. https://www.mapuexpress. org/2015/06/06/el-modelo-convencional-de-producir-alimentos-en-chile-y-de-laausencia-de-politicas-de-desarrollo-agricola/

Nodari, R. O. (2011). Ciência precaucionária como alternativa ao reducionismo científico aplicado à biologia molecular. In M. Zanoni \& G. Ferment (Orgs.), Transgênicos para quem? Agricultura, Ciência e Sociedade (pp. 39-62). MDA.

Pernambuco, M., Delizoicov, D., \& Angotti, J. A. (1988). Projeto ensino de ciências a partir de problemas da comunidade. Seminário ciência integrada e/ou integração entre as ciências: teoria e prática. Rio de Janeiro, Brasil.

Pontuschka, N. (Org.). (1993). Ousadia no diálogo: Interdisciplinaridade na escola pública. Loyola.

Prigogine, I. (2009). Ciência, Razão e Paixão (2a ed.). Livraria da Física.

Pupo, M. A. V. (2018). Por uma Ciência popular da vida: ancestralidade e agroecologia na formulação das Ciências da Natureza da Educação do Campo. Revista Brasileira Educação Campo, 3(3), 862-890. https://doi.org/10.20873/uft.2525-4863.2018v3n3p862

Rosa, S. E. (2019). Educação CTS: contribuições para a constituição de culturas de participação (Tese de Doutorado, Universidade de Brasília, Brasília, Distrito Federal). Repositório Institucional da UnB. https://repositorio.unb.br/handle/10482/39240

Roso, C. C. (2017). Transformações na Educação CTS: uma proposta a partir do conceito de Tecnologia Social (Tese de doutorado, Universidade Federal de Santa Catarina, Florianópolis, Santa Catarina). Repositório Institucional da UFSC. https://repositorio. ufsc.br/handle/123456789/187060 
Rosset, P. (2017). A territorialização da Agroecologia na disputa de projetos e os desafios para as escolas do campo. Outras Expressões.

Rossi, E. M., Melgarejo, L., Souza, M. M. O., Ferrer, G., Talga, D., Barcelos, R. O., \& Cabaleiro, F. (2020). Abelhas \& Agrotóxicos: Compilação sobre as evidências científicas dos impactos dos agrotóxicos sobre as abelhas - Petição perante a Relatoria DESCA da Comissão Interamericana de Direitos Humanos. (Em português).

Sábato, J. A., \& Mackenzie, M. (1982). La Producción de Tecnología: autónoma o transnacional. Editorial Nueva Imagen.

Samagaia, R. (2016). Comunicação, divulgação e educação científicas: Uma análise em função dos modelos teóricos e pedagógicos (Tese de Doutorado, Universidade Federal de Santa Catarina, Florianópolis, Santa Catarina). Repositório Institucional da UFSC. https://repositorio.ufsc.br/xmlui/handle/123456789/169089

Santos, R. A., \& Auler, D. (2019). Práticas educativas CTS: busca de uma participação social para além da avaliação de impactos da Ciência-Tecnologia na Sociedade. Ciência \& Educação, 25(2), 485-503.

Silva, A. F. G. A. (2004). Construção do currículo na perspectiva popular crítica das falas significativas às práticas contextualizadas (Tese de Doutorado, Pontífica Universidade Católica de São Paulo, São Paulo, São Paulo). Biblioteca Digital. https://tede2.pucsp.br/ handle/handle/22098

Silva, A. R. C. (28 de dezembro, 2021). A pandemia e o agronegócio no Brasil. Le Monde Diplomatique Brasil, 14(162), 4-5. https://diplomatique.org.br/a-pandemia-e-oagronegocio-no-brasil/

Snyders, G. (1988). A alegria na escola. Manole.

Strieder, R. B. (2012). Abordagens CTS na Educação Científica no Brasil: Sentidos e Perspectivas (Tese de Doutorado, Universidade de São Paulo, São Paulo, São Paulo). Biblioteca Digital de Teses e Dissertações da USP https:/teses.usp.br/teses/ disponiveis/81/81131/tde-13062012-112417/pt-br.php

Taibo, C. (2019). Colapso: capitalismo terminal, transição ecossocial, ecofascismo. UFPR.

Toledo, V. M., \& Barrera-Bassols, N. (2015). A memoria biocultural: a importância ecológica das sabedorias tradicionais. Expressão Popular.

Varsavsky, O. (1975). Ciencia, política y cientificismo (6 $6^{\mathrm{a}}$ ed.). Centro Editor de América Latina.

Varsavsky, O. (1976). Por uma Política Científica Nacional. Paz e Terra. 
Décio Auler

Universidade Federal de Santa Maria Santa Maria, Rio Grande do Sul, Brasil auler.ufsm@gmail.com

\section{Editora Responsável}

Stefannie Ibraim

Manifestação de Atenção às Boas Práticas Científicas e de Isenção de Interesse

Os autores declaram ter cuidado de aspectos éticos ao longo do desenvolvimento da pesquisa e não ter qualquer interesse concorrente ou relações pessoais que possam ter influenciado o trabalho relatado no texto. 